\title{
Urinary thioether of employees of a chemical plant
}

\author{
H. VAINIO, H. SAVOLAINEN, AND I. KILPIKARI
}

From the Department of Industrial Hygiene and Toxicology, Institute of Occupational Health, SF-00290

Helsinki 29, and the Medical Department, Nokia Corporation Inc., SF-37100 Nokia, Finland

ABSTRACT The thiols in the morning urine of 224 employees of a chemical plant were determined after alkaline hydrolysis of all urinary thioethers. The highest thioether excretion was found in rubber workers and radial tyre builders in comparison with clerks, plastic monomer mixers and footwear preparers. Smoking and medication tended to increase thioether excretion. Urinary thioether determination may prove to be a valuable tool in assessing exposure to mixtures of chemicals regardless of the route of absorption.

Occupational malignancy such as bladder and lung cancer and gastrointestinal neoplasms have been found in workers in the rubber industry (British Rubber Manufacturers Association Health Research Project, 1976; Fox and Collier, 1976). The recognition of the potential hazards of continued chemical exposure is therefore vitally important in rubber and other chemical industries. Attention should be paid to chemical exposure as a whole, rather than to single chemical compounds, if control of the general occupational hazard is to be sought. Unfortunately, so far no biological method for monitoring, has been readily applicable.

Mercapturic acid and other thioethers are the end-products of a variety of potentially harmful electrophilic compounds. Despite the fact that the first reports on the urinary excretion of mercapturic acids were published almost a century ago (Baumann and Preusse, 1879; Jaffe, 1879), only recently has the appearance of thioether derivatives in urine been suggested to be a useful indicator of exposure to potential alkylating agents (SeutterBerlage et al., 1977).

In the present study we have determined the content of mercapturic acid conjugates and other thioethers in the urine of employees from various divisions of a chemical plant.

\section{Materials and methods}

SUBJECTS

The urine of 83 male and 141 female employees in a large Finnish chemical factory was analysed for thioether content. Sixty-three of the workers were

Received for publication 10 September 1977 Accepted for publication 12 January 1978 smokers at the time of the urine sampling and 49 were receiving medication (Tables 1 and 2).

The distribution of different classes of medicaments was as follows, in women: contraceptive pills $30 \%$, blood pressure drugs $20 \%$, diuretics $18 \%$ and others $32 \%$, including heart medicaments. A similar picture was seen for the drugs taken by the men, with the exception of contraceptive pills.

Tables 1 and 2 show the urinary thioether excretion of the men and women respectively, according to their occupation. The tyre builders have been divided into two groups according to whether they were producing cross-ply or radial tyres. The reason for this division is that the two procedures differ slightly from each other as far as the chemicals are concerned. Hexamethylene tetramine and resorcinol are used in radial tyre building but not in crossply tyres. The footwear preparers have been divided into two groups according to the degree of exposure to organic solvents; one group (I) worked in an older section of the plant and was more exposed than the other (II) which worked in a newer area. The workers from the rubber-making division of the plant were mainly operators who weighed or mixed chemicals, but there was also one instructor, one trucker and three shift workers. Workers from the electrocondensator division, who were exposed to polychlorinated biphenyls, were included for comparison as were the tissue processers and packers from another division of the plant. The processers and packers handle freshly manufactured and printed paper products. They are exposed to dust and evaporating printers' chemicals.

Samples of freshly voided morning urine were brought to the medical station of the plant on Thursday and Friday mornings. They were frozen immediately at $-25^{\circ} \mathrm{C}$ without preservatives. 
Table 1 Urinary thioether excretion of male employees

\begin{tabular}{|c|c|c|c|c|}
\hline \multirow[t]{2}{*}{ Smoking habit } & \multicolumn{4}{|c|}{ Thioether excretion* } \\
\hline & Clerks & Condensator workers & Rubber workers & Plastic mixers \\
\hline $\begin{array}{l}\text { Non-smokers } \\
\text { without medication } \\
\text { with medication }\end{array}$ & $30 \pm 7(20)$ & $\frac{28}{-} \pm 7(8)$ & $\begin{array}{l}51 \pm 17(3) \dagger \\
52 \pm 26(2)\end{array}$ & $\begin{array}{l}26 \pm 4(10) \\
31 \pm 5(6)\end{array}$ \\
\hline $\begin{array}{l}\text { Smokers } \\
\text { without medication } \\
\text { with medication }\end{array}$ & $32 \pm 6(11)$ & $\underline{30} \pm 1(2)$ & $\begin{array}{l}57 \pm 9(11) \ddagger \\
71 \pm 2(2)\end{array}$ & $\underline{30} \pm 8(8)$ \\
\hline
\end{tabular}

* $\mu \mathrm{mol} / \mathrm{mmol}$ creatinine $\pm \mathrm{SD}$ with number of subjects in brackets.

$\dagger$ Differs from non-smoking clerks at $\mathbf{P}<0.05$.

‡Differs from smoking clerks at $P<0.0025$.

Table 2 Urinary thioether excretion of female employees

\begin{tabular}{|c|c|c|c|c|c|c|}
\hline \multirow[t]{3}{*}{ Smoking habit } & \multicolumn{6}{|c|}{ Thioether excretion* } \\
\hline & \multirow[t]{2}{*}{ Clerks } & \multicolumn{2}{|l|}{ Tyre builders } & \multicolumn{2}{|c|}{ Footwear preparers } & \multirow{2}{*}{$\begin{array}{l}\text { Tissue } \\
\text { processors } \\
\text { and packers }\end{array}$} \\
\hline & & Cross-ply group & Radial group & Group I & Group II & \\
\hline $\begin{array}{l}\text { Non-smokers } \\
\text { without medication } \\
\text { with medication } \\
\text { Smokers }\end{array}$ & $\begin{array}{l}37 \pm 9(16) \\
44 \pm 24(6)\end{array}$ & $\frac{37}{-} \pm 8(12)$ & $\begin{array}{l}63 \pm 14(16) \dagger \\
73 \pm 10(4) \S\end{array}$ & $\begin{array}{l}34 \pm 5(8) \\
41 \pm 4(9)\end{array}$ & $\begin{array}{l}32 \pm 5(10) \\
46 \pm 13(7)\end{array}$ & $\begin{array}{l}46 \pm 8(16) \ddagger \\
41 \pm 5(8)\end{array}$ \\
\hline $\begin{array}{l}\text { without medication } \\
\text { with medication }\end{array}$ & $\begin{array}{l}44 \pm 19(13) \\
52 \pm 23(3)\end{array}$ & $\frac{36}{-} \pm 8(4)$ & - & $\frac{32}{-} \pm 6(2)$ & $\begin{array}{r}29 \\
35\end{array} \frac{5(3)}{(2)}$ & $\underline{4} \pm 18(2)$ \\
\hline
\end{tabular}

$* \mu \mathrm{mol} / \mathrm{mmol}$ creatinine $\pm \mathrm{SD}$ with number of subjects in brackets. + Differs from non-smoking clerks at $P<0.0025$

$\neq$ Differs from non-smoking clerks at $P<0.005$.

$\S$ Differs from non-smoking clerks with medication at $P<0.05$.

ANALYSIS OF THIOETHERS

Five milligrams of ascorbic acid were added to a 10 $\mathrm{ml}$ sample of urine; proteins were removed from a $2 \mathrm{ml}$ aliquot of this sample by the addition of $3 \mathrm{ml}$ of a reagent containing $2 \mathrm{M}$ phosphoric acid, $5 \mathrm{mM}$ EDTA and $5 \mathrm{M}$ sodium chloride. The mixture was then centrifuged at $1000 \mathrm{~g}$ at room temperature for 15 minutes, and $0.25 \mathrm{ml}$ of $5 \mathrm{M}$ sodium hydroxide was added to $1 \mathrm{ml}$ of the supernatant in stoppered glass tubes. The tubes were incubated in a boiling water bath for 50 minutes and then cooled. Subsequently $0.5 \mathrm{ml}$ of $2.5 \mathrm{M}$ hydrochloric acid was added, and $0.5 \mathrm{ml}$ of the neutralised solution was mixed with $4 \mathrm{ml}$ of $0.07 \mathrm{M}$ phosphate buffer $(\mathrm{pH}$

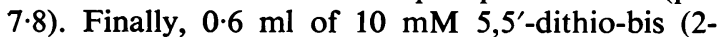
nitro-benzoic acid) in $0.07 \mathrm{M}$ phosphate buffer ( $\mathrm{pH}$ 7.8) was added (Ellman, 1959). After the mixture had been thoroughly mixed and incubated for five minutes at room temperature, its absorbance was measured with a Pye Unicam spectrophotometer at $412 \mathrm{~nm}$. Non-hydrolysed urine blanks were treated similarly, except that water was added in place of the $5 \mathrm{M}$ sodium hydroxide and $2.5 \mathrm{M}$ hydrochloric acid. For the standards, appropriate amounts of thioglycolic acid were dissolved in water to form concentrations of $2 \cdot 0,1 \cdot 5,1 \cdot 0,0.5$, and $0.2 \mathrm{mM}$ of the acid; the standards were analysed together with the urine samples.

Urinary excretion of creatinine was measured from the same samples with picric acid reagent, and the amount of hydrolysed thiol groups was related to the creatinine excretion.

\section{ACCURACY AND PRECISION OF THE CHEMICAL ANALYSIS}

An error of $-4 \%$ was detected at the hydrolysed thioether level of $0.5 \mathrm{mM}$ by the analysis of ten samples with added thioether. At the thioether level of $1.2 \mathrm{mM}$ the error was $-8.3 \%$. The intra-series variation in precision was $5.5 \%$ with a day-to-day variation of $5.7 \%$ (10 samples).

Statistical evaluation of the results was performed with the aid of Student's $t$-test.

\section{Results}

The urinary thioether excretion of the workers from the rubber-making division of the plant was considerably higher than that of the male clerks, but no differences were found between the PCB workers and the clerks (Table 1). In general the women tended to excrete more thioethers in their urine 
than did the men. The highest thioether excretion was found among radial tyre builders; cross-ply tyre builders excreted less of these compounds (Table 2). Smoking and medication tended to increase urinary thioethers.

\section{Discussion}

The analytical method used in our study to determine urinary thioether excretion is satisfactory provided that ascorbic acid is added to the urine samples. Analysis under nitrogen or without nitrogen or ascorbic acid leads to a larger variation in the result (coefficient of variation $20 \%$ ). The mode of action of ascorbic acid is obscure although its antioxidant effect may be significant.

The slightly higher thioether excretion of nonsmoking female clerks in comparison to that of the male clerks is intriguing although it may be explained by oestrogen conjugates (Elce and Chandra, 1973). Smoking induced a slight increase in the thioether excretion of all the groups. Most of the medicines used by the test subjects had a similar effect.

The office in which the clerks worked is situated a long way from the rest of the plant, and chemical exposure of these employees is therefore negligible. Rather high dust concentrations can be measured in the mixing department of the rubber-making division, while the tyre builders and the footwear preparers are exposed to low atmospheric levels of organic solvents.

The women who build radial tyres excreted unexpectedly high levels of urinary thioether. The recorded difference in thioether excretion between workers manufacturing radial tyres as compared with cross-ply tyres is puzzling, but may be attributable to differences in the chemicals used. In radial tyres, hexamethylene tetramine and resorcinol are currently used as additives to the tyre rubber to improve its adhesion and physical properties. The data on the carcinogenicity of hexamethylene tetramine are conflicting (Holmberg and Sjöström, 1977). The workers manufacturing radial tyres are exposed through the skin almost entirely, by touching the tyres with their bare hands. People working in the tyre sector of the rubber industry seem also to be exposed to the risk of occupational cancer (Fox and Collier, 1976). The assessment of their chemical burden has been impossible so far, but our measurements of thioethers are very promising. The male workers from the rubber-mixing department also had increased thioether excretion when compared with male clerks. The observed difference between non-smoking female tissue processors and clerks (Table 2) might be accounted for by the exposure of the former group to printers' chemicals and possibly to pyrolysis products given out by the seaming machines. Similar groups are easily found in the chemical industry and it will be interesting to study them and compare the results with those reported here.

We wish to thank Mrs Hilkka Järventaus for her skilful technical assistance, the staff of the medical department of the Nokia Corporation for their contribution, and the Finnish Academy for its financial aid.

\section{References}

Baumann, E., and Preusse, C. (1879). Über bromphenylmercaptursäure. Berichte der Deutschen Chemischen Gesellschaft, 12, 806-810.

British Rubber Manufacturers Association Health Research Project, University of Birmingham, Department of Social Medicine (1976). Report, pp. 1-19. January, 1976. BRMA: Birmingham.

Elce, J. S., and Chandra, J. (1973). Estrogen mercapturic acids in the adult male rats. Steroids, 22, 699-705.

Ellman, G. L. (1959). Tissue sulfhydryl groups. Archives of Biochemistry and Biophysics, 82, 70-77.

Fox, A. J., and Collier, P. F. (1976). A survey of occupational cancer in the rubber and cablemaking industries: analysis of deaths occurring in 1972-1974. British Journal of Industrial Medicine, 33, 249-264.

Holmberg, B., and Sjöström, B. (1977). Toxikologisk översikt över gummikemikalier. Arbetarskyddsstyrelsen, Stockholm. Undersökningsrapport, 19, 1-100.

Jaffe, M. (1879). Über die nach einführung von brombenzol und chlorbenzol im organismus entstehenden schwefelhaltigen säuren. Berichte der Deutschen Chemischen Gesellschaft, 12, 1092-1098.

Seutter-Berlage, F., van Dorp, H. L., Kosse, H. G. J., and Henderson, P. T. (1977). Urinary mercapturic acid excretion as a biological parameter of exposure to alkylating agents. International Archives of Occupational and Environmental Health, 39, 45-51. 